\title{
Innovating the didactical methodologies applied in Universities through Second Life and Practice Firm: case study
}

Laura Tampieri*

${ }^{*}$ Correspondence: laura.tampieri@unibo.it Department of Management, University of Bologna, Via Capo di Lucca, 34, 40126 Bologna, BO, Italy

\begin{abstract}
The paper analyses and discusses Second Life and Practice Firm as two innovative methodologies used in education considering the recent experiences carried out by Bologna University-Forli School of Economics, Management and Statistics. Although there are fast advancements in ICTs frontier for teaching and learning and their criticisms, Higher Education Institutions increasingly used Second Life and Practice Firm to test new didactical methodologies. All these topics will be discussed by analysing the experiences in progress carried out by Bologna University-Forlì School of Economics, Management and Statistics in the usage of Second Life, started in 2008, and of Practice Firm through which Perting, the first simulated firm established in an Italian University, operates in consulting services and ICT goods trade. The research question refers to: how we can connect Practice Firm and Second Life in the learning transfer of knowledge, capacities and skills? The paper outlines the main features and implications of these didactical methodologies and how they can be connected for improving the educational process undertaken by Universities.
\end{abstract}

Keywords: Second Life, Practice Firm, Learning, Didactical methodologies

\section{Background}

Today we live in a world where the limited spatial boundaries are overcome by virtual ones derived from the advancements reached in ICTs that pushed virtual communities to share information, interests and targets in a wider environment.

In last years, virtual words (VWs) such as Second Life (SL) are increasingly used by Higher Education Institutions (HEIs) as shared, interactive and immersive environments where people identified by avatars communicate, collaborate, innovate and trade (Foster 2008).

Second Life is an online three-dimensional virtual environment launched by Linden Labs in 2003 that explores and develops different areas of intervention such as education and training; communication and collaboration; marketing, sale and innovation (Kaplan and Haenlein 2009).

In SL, people are represented by avatars (their 3D representations) and communicate through chat (voice or written text), note cards, their profiles or Instant Messages in the case she/he is not online at the moment she/he logs in. Moreover, they can immerse

(C) 2015 Tampieri. This article is distributed under the terms of the Creative Commons Attribution 4.0 International License (http:// creativecommons.org/licenses/by/4.0/), which permits unrestricted use, distribution, and reproduction in any medium, provided you give appropriate credit to the original author(s) and the source, provide a link to the Creative Commons license, and indicate if changes were made. 
themselves in this world and experience the sense of walking, jumping and flying as well as create virtual objects (Mackenzie et al. 2009).

The relevance of SL for educational purposes is well known amongst communities with many Universities that deliver courses and/or realize researches (Michels 2008) and educational organizations as the cases New Media Consortium (NMC) and International Society for Technology in Education (ISTE) that have built islands (Inman et al. 2010).

Moreover through Second Life Educators (https://lists.secondlife.com/cgi-bin/mailman/listinfo/educators), teachers and researchers are facilitated to cooperate in projects and exchange advices on educational issues.

In the perspective of knowledge production, as reported by Wang and Burton (2013), studies on SL were addressed mainly to foster constructivist and experiential learning, including collaborative and action learning, project- and problem-based learning and situated cognition.

As it concerns Practice Firm (PF) methodology (or Simulimpresa, http://www.simulimpresa.com), this consists in the reproduction of a real organization in a classroom with the application of "learning by doing" principle and it is increasingly diffused in Universities for entrepreneurship education. This methodology is disseminated in other typologies of organization such as vocational training centres, technical and professional public high schools, companies, chambers of commerce and trade unions.

Aside of this process companies could transfer their experiences mothering the PFs and delivering directly their know how to teachers and students assuming the role of Business Partner.

The main purpose of this methodology is to put at the centre of the educational process the students that, simulating the operations of a real company, develop multidisciplinary skills starting from their individual peculiarities.

The paper analyses the role of PF and SL in the education field facing the following research question: how we can connect PF and Second Life in the learning transfer of knowledge, capacities and skills?

The paper starts with the theoretical background on SL and PF followed by the analysis of the main features of these didactical methodologies. Then, the paper examines Bologna University experiences underling the results. In "Conclusions" the limitation of the findings and the future perspectives are defined.

\section{Theoretical background on Second Life and Practice Firm}

In the education field a large number of authors address many concepts such as virtual reality (VR), augmented reality (AR) and VWs with different meanings.

According to Keppell and Macpherson (1997), VR is "a situation where a person was immersed into a computer-generated environment that bores strong similarities with reality".

The concept of VR includes a psychological and a technological perspective: the first outlines the status of users' mind in the behaviour between the real and virtual environment whilst the technological view connects VR to a platform where head-mounted visual display units and motion-tracking gloves are present (Fallman et al. 1999). 
Another aspect in VR is the way of interaction between the user and the computergenerated environment. On this purpose, Keppell and Macpherson (1997) stated that "the users manipulate what is perceived to be "real" objects in the same manner as they would manipulate them in the real world, as opposed to the typing, pointing and clicking you traditionally use to manipulate objects when you interact in other computer environments".

Virtual reality provides many implications for knowledge production as the learning development goes in four directions (Winn 1993). The first is addressed to impart objective knowledge to the learner; the second focuses on the strategies used to reduce the cognitive load on students; the third is about the connection between the user and the information presented using tools as intelligent tutors. The fourth orientation is set on the construction of the knowledge by the learner, "not delivered by the courseware" that derives by the advancements of VR. Such evolution together with the ways in which knowledge is created and negotiated in virtual environments is outlined by the constructivist research (Moore 1995).

In SL environment the learner constructs its own understanding of content, creating direct connections and meaning. Thus the learner develops the ability to create and use objects within a knowledge-building community in which collaborative strategies could be implemented through mentors, peer role models, open classrooms and role reversal (Coffman and Klinger 2007).

Different is the concept of AR defined by Mekni and Lemieux (2014) in which the following characteristics emerged: (1) combination of real and virtual dimensions; (2) interaction in real time and (3) registration in 3-D. In particular, the authors stated that "it combines technologies that enable real-time mixing of computer-generated content with live video display allowing to make an increased perception of reality". AR finds application in different sectors as marketing, tourism, logistics and education. In this last field, AR allows the connection between virtual objects and real environments, so that learners can visualize complex spatial relationships and abstract concepts, experience phenomena that could not be realized in the real context (Billinghurst and Dunser 2012). Moreover, it is possible to interact with two- and three-dimensional synthetic objects in the mixed reality (Yuen et al. 2011).

As it concerns VWs, Merchant et al. (2014) stated that "Virtual worlds are characterized by: the illusion of being in a 3-D space, ability to build and interact with the 3D objects, digital representation of learners in form of avatar, and ability to communicate with other learners in the virtual worlds. VWs are open-ended environments in which users design and create their own objects, whilst the simulations and games produce structured situation".

At the early stage of virtual reality technologies, development met some problems as the financial feasibility owing to the high cost for procurement and maintenance of sophisticated devices and physical, psychological burdens as repetitive strain injuries, disorientation and dissociation can be outlined (Merchant et al. 2014).

Although these criticisms exist, the rapid enforcement in the processing capacity of computers led to the deployment of desktop-based virtual reality technologies in education. The reduction of technologies costs together with the high-speed internet connection further encouraged the use of these technologies in didactical activities. 
Moreover, the learners' engagement can be strengthened through low-cost peripheral devices such as headphones, smart glasses and data gloves.

In addition new possibilities of simultaneous and collaborative working for more than one user are developed in SL creating a rich and dynamic learning environment where the learners think critically about the topics and widen the perspective of the learning object outside of the classroom into SL (Coffman and Klinger 2007).

As it regards PF, the literature does not provide a such wider spectrum as for SL, although this methodology is not a didactic novelty.

The definition of PF here indicated comes from the website of EUROPEN-PEN International that is the worldwide practice enterprise network in which PF (also known as simulated enterprise, training firm, virtual enterprise) is "a simulated business set-up experienced by students, during their studies, under the supervision of teachers/tutors. As innovative centre of vocational learning, it runs like a real business, using a real firm's business procedures, products and services".

This methodology mainly aims to improve students' practical skills connected to a firm functioning. The key actors are the students who have to realize assigned targets by working in team, problem solving and decision taking. Teacher/tutor only has the role of supervisor and facilitator of the learning process (Moore 2004).

In these terms, PF methodology applies the principle of learning by doing (Reese 2011) as students doing business activities, e.g. preparation of employees' contracts, market analysis, elaboration of products catalogue, learn about such operations.

From the perspective of knowledge production, this methodology enhances the experiential learning with a focus on collaborative, action- and problem-based learning.

The connection with the world of enterprises is ensured by the Business Partner that provides data, information, materials, advices and consultancy to PF in its operative working.

\section{Main educational implications of Second Life and Practice Firm}

The use of SL and PF as didactical methodologies implemented in Universities gives evidences to different implications that produce several innovative educational opportunities.

The choice of SL for some educators derives from its manipulation of space and time limited only by imagination and from the high degree of realism with minimal risk (Mahon et al. 2010).

In SL the main features can be summarized as follows (Tampieri 2012):

- Immersivity: participants feel a sense of presence in SL that seems to be in the real context.

- Interactivity: through voice and text tools in SL avatars can interact each other in real time.

- Customizability: avatars can create objects as results of creative human imagination. This produces a virtual environment that could rapidly change, evolve and sometimes disappear in real time. 
- Accessibility: SL is an open and accessible virtual world that contains stimulating educational lands with many art galleries, libraries, museums and research centres. Most of them are open and free access.

Adding to the mentioned issues, the same environment of SL is itself an area of learning for students/avatars that increase their knowledge from this VW.

In universities, these features determine many implications for the teaching: first, the planning and implementation of rich and dynamic educational environments that combine different tools as distance learning, practice management, VR, AR, simulations for students and instructors. Second, the creation of a virtual networked classroom where students and teachers, coming from anywhere in the world, can share and interact. In such a way, the physical barriers can be overcome by sharing a common virtual space as SL. Third, universities seek to augment existing curriculum and learning contents considering the advancements made in ICTs to reduce the gap between the university courses and the labour of market in which the technology plays a central role. Moreover, a more informal interaction between students and universities can be outlined in SL also due to a layer of semi-anonymity that enables some students to feel more comfortable in interacting and collaboration.

These implications have to consider some criticisms and limits as outlined by Filho et al. (2006):

- the high level of implementation costs,

- the high time required to integrate systems with existing processes,

- the high network bandwidth access requirements,

- the lack of ground rules and privacy, security and legal protection for in-world activities.

In addition, we can count the initial requirement for participants of technical and technological skills to enter and use a 3D environment.

Welch (2007) individuates in slow service, frequent crashes, the requirement to continually download updated versions as relevant criticisms in using SL.

Another limitation derives from the technological dimension in the failure of teleports, in the disappearance of inventory and in the stalling of "transaction loops" (Salomon 2007).

As it concerns PF, there are some relevant elements as:

1. Sense of responsibility. Students assume roles and are responsible for fulfilling the operative tasks assigned by teachers/tutors. This aspect finds expression in the documents and operations produced by each organizational unit/office/department. According to cause-effect relationship, each decision produces an immediate effect from a practical perspective enforcing the sense of responsibility to participants.

2. Team working. Students are required to work in team supporting each others in doing activities. 
3. Proposal capability. Each participant is encouraged to make proposals in improving the enterprise functioning. These new ideas are discussed with the other colleagues before taking a decision on the matter.

4. Autonomy. Participants, once received tasks, try to accomplish them analysing and solving problems for reaching in autonomy the achieved results.

Practice Firm methodology faces the main problem connected to the lack by students at universities in practical know how of the working environment. To bridge this gap between the offer of courses by universities and the demand by the market, this innovative didactical methodology is implemented combining the stable learning environment of the classroom with the real-world experience of companies.

The main implications for teaching in universities are to make the learning more effective as the environment in which the simulation is done faithfully reproduces the reality.

Moreover, this methodology creates a collaborative environment based on the interactivity amongst participants with a continuous feedback on learning process and confirmed by obtained successes or realized mistakes.

\section{Methods: the experiences of Second Life and Practice Firm carried out by Bologna University}

As it concerns the methodological framework, the paper analyses the experiences of Practice Firm (Simulimpresa) methodology realized since 2001 by Bologna UniversityForlì School of Economics, Management and Statistics (UNIBO) with the startup of Perting Ltd, the simulated enterprise that operates in consulting sector and ICT goods trade. Moreover, the experimental application of SL by Perting team has been examined.

The method of case study contributes to better explain the experimental experiences of PF and SL that have been realized by UNIBO. To this purpose, the paper describes such experiences focusing on the main organizational aspects of learning and teaching framework.

From the educational profile Simulimpresa course, since A.Y. 2013/2014, has been realized during the period September-December with a break of 15 days in November for intermediate tests. It is an optional course of $40 \mathrm{~h}$ for 6 ECTS with practical lectures of $3-4 \mathrm{~h}$ (Table 1$)$.

Simulimpresa goes through Perting virtual firm functioning which is composed by these main organizational units: human resource administration; general affairs; accounting; management control; treasury and finance; tax; marketing; foreign sales; national sales; office and warehouse; web and international projects. Each of them moves through tasks delivered at the beginning of the lecture by teacher/tutor.

In Table 2, we can summarize the main tasks assigned to Perting organizational units in A.Y. 2014/2015.

In addition to this educational framework, UNIBO realized two experimental modules on Simulimpresa for resilience during the period March-May 2015. The first named "Simulimpresa for Virtual, Augmented Reality and Media Context in Resilience" of $20 \mathrm{~h}$ involved 15 students and 5 teachers/tutors, with the following organizational units: General Secretary and Networking; International Project Network Simulimpresa; Emergency and resilience in virtual reality-Second Life; News room in newspaper; ICT operative 
Table 1 The educational profile of Simulimpresa course

\begin{tabular}{lllcl}
\hline Academic year & No. of teachers & No. of tutors & No. of students & No. of hours \\
\hline $2001 / 2002$ & 1 & 1 & 51 & 50 \\
$2002 / 2003$ & 1 & 1 & 52 & 50 \\
$2003 / 2004$ & 1 & 2 & 48 & 50 \\
$2004 / 2005$ & 1 & 2 & 57 & 50 \\
$2005 / 2006$ & 1 & 2 & 63 & 50 \\
$2006 / 2007$ & 1 & 2 & 54 & 50 \\
$2007 / 2008$ & 1 & 2 & 55 & 50 \\
$2008 / 2009$ & 2 & 7 & 120 & 50 \\
$2009 / 2010$ & 2 & 2 & 76 & 50 \\
$2010 / 2011$ & 1 & 2 & 116 & 50 \\
$2011 / 2012$ & 1 & 2 & 75 & 50 \\
$2012 / 2013$ & 1 & 1 & 36 & 50 \\
$2013 / 2014$ & 1 & 1 & 23 & 40 \\
$2014 / 2015$ & 1 & 1 & 28 & 40 \\
\hline
\end{tabular}

rooms. The second, "Simulimpresa in Resilience for Cultural Heritage", was composed by 13 students and 5 teachers/tutors for $20 \mathrm{~h}$ with: General Secretary and Networking; International Project Network Simulimpresa; Second Life with a focus on Smart Glasses; Disaster mitigation and resilience in cultural heritage as organizational units.

The paper considers the experimental activities realized in SL managed by Perting team during these two experimental modules on the basis of the previous researches carried out by the author that focused on the startup of enterprises in SL and in PF (Tampieri 2009, 2011).

In 2008, SL was implemented in UNIBO for educational purposes with a land up-todated over the years. A recent image of the land is showed in Fig. 1.

The land is structured in: 1) Perting building with offices and a seminar room to be used for lectures/meetings/workshops realization, 2) New Fashion Perspectives Atelier for the sale of fashion products and 3) Exposition area in which UNIBO international projects are disseminated as RESINT "Collaborative Reformation of Curricula on Resilience Management with Intelligent Systems in Open Source and Augmented Reality" and CENEAST "Reformation of the Curricula on Built Environment in the Eastern Neighbouring Area".

In particular, Perting building has been used to test lectures/seminars/workshops during Simulimpresa course.

On this purpose, the activities undertaken by Perting team during the period MarchMay 2015 were addressed to the realization of (1) researches, (2) dissemination and (3) seminars/workshops.

First, students acquired knowledge about SL by the tutor with the creation of Avatar and basic operations such as moving and flying; creating of objects; taking snapshot, inserting and managing files of promotion materials.

These operations were followed by the research on resilience management using chat with other avatars, visiting lands of organizations operating in this field with the aim for students to become more familiar with SL and to interact and share experiences with different typologies of stakeholders as people, organizations and NGOs 
Table 2 Summary of operative units and tasks

\begin{tabular}{|c|c|c|c|}
\hline No. & ou & No. students & Tasks \\
\hline 1 & $\begin{array}{l}\text { Human resource } \\
\text { administration and } \\
\text { general affairs }\end{array}$ & 4 & $\begin{array}{l}\text { Contracts of employee's assumption of Perting; elabora- } \\
\text { tion of Perting microstructure, signing of labour } \\
\text { contracts; administration and management of human } \\
\text { resources. Communications with Italian and foreign } \\
\text { simulated enterprises and reopening of the activities } \\
\text { and sending promotions. Exchange of information } \\
\text { with the Advisory Department and verbal recruitment } \\
\text { of Perting's employee, in connection with Project Units }\end{array}$ \\
\hline 2 & Accounting & 4 & $\begin{array}{l}\text { Learning on the usage of software OS1; view of the bal- } \\
\text { ance before adjustment to produce the balance of the } \\
\text { previous exercise in connection with Project Units }\end{array}$ \\
\hline 3 & Management Control & 4 & $\begin{array}{l}\text { Annual Budget: training on OS1. Adjustment entries: } \\
\text { draw up financial statement before the closure }\end{array}$ \\
\hline 4 & Treasury, finance and Tax & 2 & $\begin{array}{l}\text { Economic situation and IBAN: check of bank communi- } \\
\text { cations. Sending F24 filled by the fiscal office. Printing } \\
\text { tickler made by accounting department and check } \\
\text { customers and suppliers expired. Sending payment } \\
\text { reminder to customers and suppliers. Treasury budget. } \\
\text { Preparing F24 for treasury. Increasing Fiscal variation } \\
\text { on gross profit and calculating Ires }\end{array}$ \\
\hline 5 & Marketing & 3 & $\begin{array}{l}\text { Market analysis through European database; communi- } \\
\text { cation with Italian and foreign enterprises; updating } \\
\text { the catalogue in paper and on line; production of } \\
\text { promotional materials; customer satisfaction surveys, } \\
\text { in connection with Project Units }\end{array}$ \\
\hline 6 & Sales and warehouse & 5 & $\begin{array}{l}\text { Learning about the procedures for fulfilment of modules } \\
\text { to foreign firms; execution of received foreign orders; } \\
\text { issuing of sale documents to both European Union } \\
\text { (EU) and non-EU countries. Elaboration of adjustment } \\
\text { records; issuing of national invoices. Updating stock } \\
\text { management and online orders based on goods } \\
\text { received from customers. Purchases from other Italian } \\
\text { simulated enterprises: process }\end{array}$ \\
\hline 7 & CAMUS project & 2 & $\begin{array}{l}\text { Project management, preparation of proposal on } \\
\text { "Recovering the Historical Heritage on catastrophic } \\
\text { events in the Museum of Post and Telecommunica- } \\
\text { tions". Contacting university partners to implement } \\
\text { Simulimpresa. Organization of videoconferences with } \\
\text { foreign universities }\end{array}$ \\
\hline 8 & CARO project & 2 & $\begin{array}{l}\text { Project management, preparation of proposal on "Educa- } \\
\text { tion for Operative Room Staff". Contacting university } \\
\text { partners to implement Simulimpresa. Organization of } \\
\text { videoconferences with foreign universities }\end{array}$ \\
\hline 9 & CARG project & 2 & $\begin{array}{l}\text { Project management, preparation of proposal on "Crea- } \\
\text { tion of an Agency for river governance". Contacting } \\
\text { university partners to implement Simulimpresa. Organ- } \\
\text { ization of videoconferences with foreign universities }\end{array}$ \\
\hline
\end{tabular}

Source: Tampieri (2015)

Moreover, the dissemination of international projects in progress, Simulimpresa experiences and their connection with the virtual network and planned seminars/workshops was carried out by Perting Team.

The final result is expressed by the seminar "Resilience management in Second Life", realized on 27th March 2015 (Figs. 2, 3) with also the participation of the virtual firms Zuvedra (Lithuania) and Celatus (Kazakhstan).

The other event was the workshop "Resilience management for cultural heritage in Second Life", realized on 18th May 2015, in which representatives of virtual enterprise 


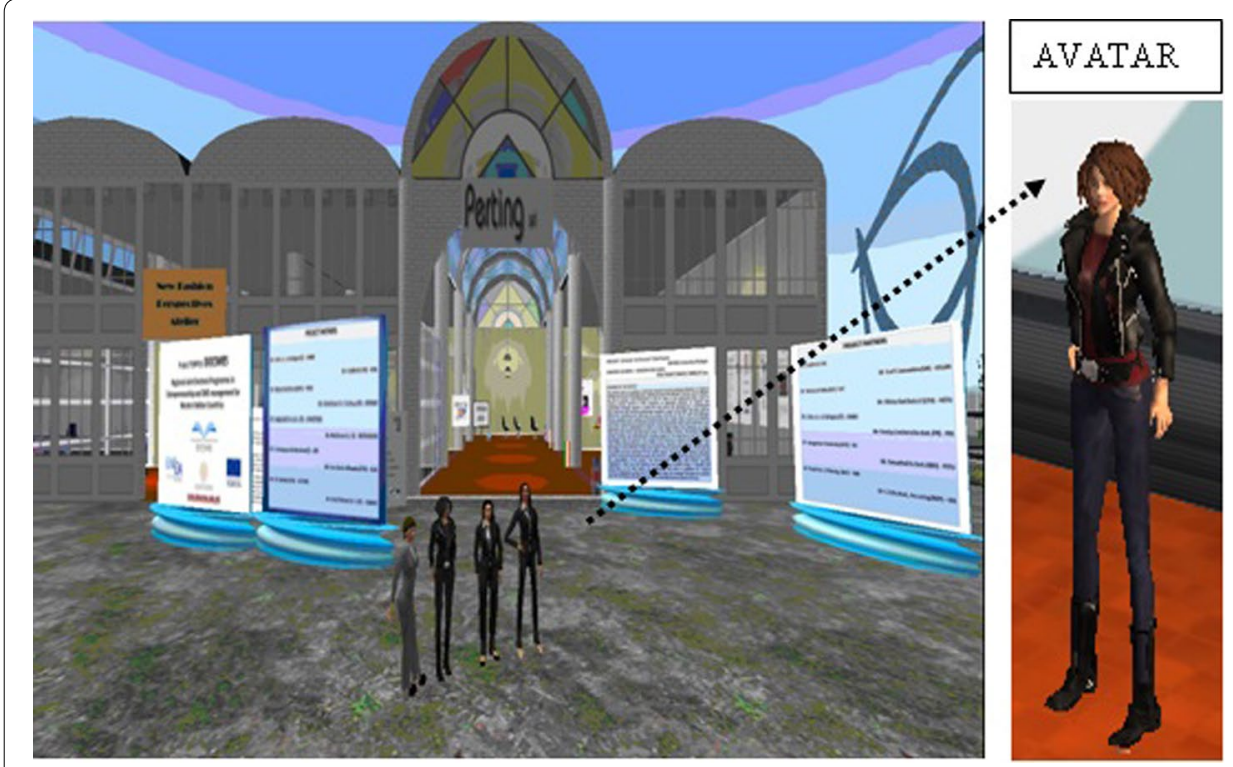

Fig. 1 Perting land at http://slurl.com/secondlife/kouhun/246/248/54 (May 2015)

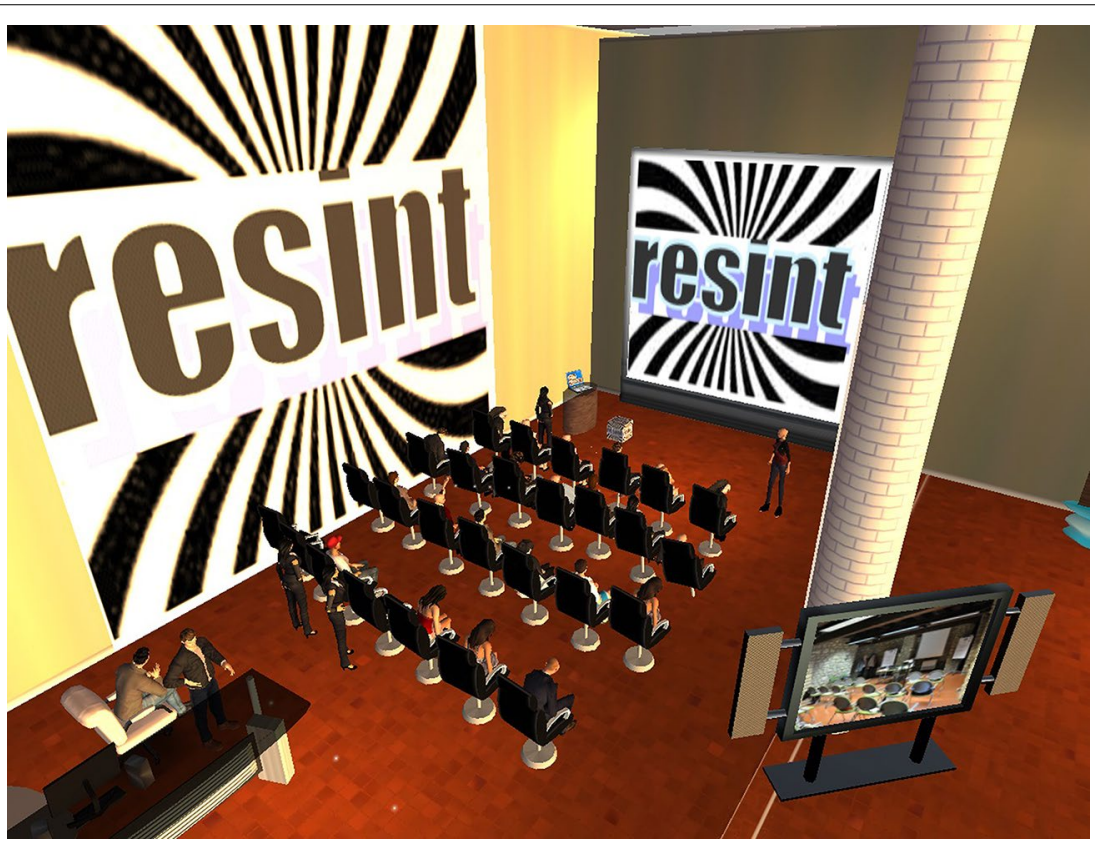

Fig. 2 The overview of seminar in Second Life

Celatus intervened with a speech on their company giving evidence to the networked system.

The educational elements (Fig. 4) that can be summarized using SL in education are: VR and AR as expressions of the environment in which avatars take lecture; the learning contents deriving from the slides projected in the screen managed by the teacher.

In addition, we can outline: the classroom with seats, the networked system in which students/teachers can share educational contents and project management summarized 


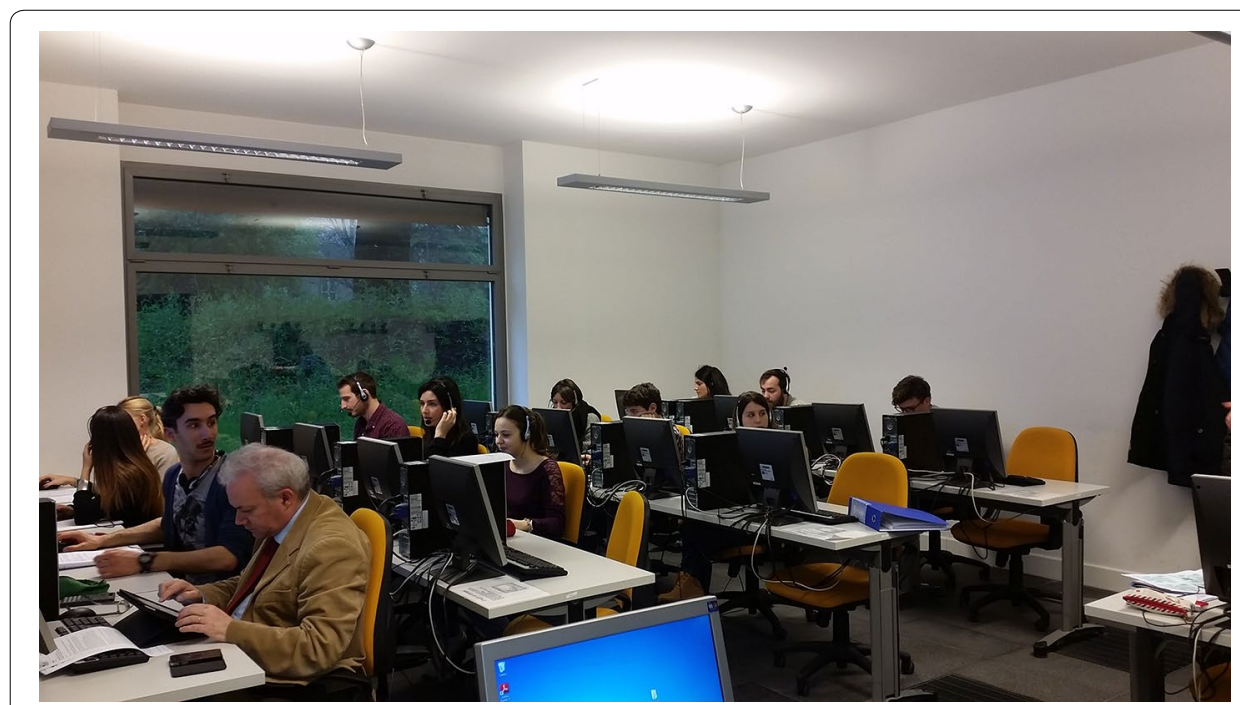

Fig. 3 The overview of seminar in classroom

in RESINT as financial support to use open-source platform in intelligent systems and augmented reality on resilience topics in universities.

\section{Results and discussion}

The main results can be summarized as follows:

1. In 2008 with the implementation of SL in Simulimpresa course, the number of students increased from 55 of the A.Y. 2007/2008 to 120 related to A.Y. 2008/2009. This finding underlines the high attractiveness of SL for students.

2. The use of SL for realizing lectures/seminars/workshops allows to widen the audience with the potential participation of all avatars that are log in at the moment of the event. For instance to the seminar hold in SL on 27th March 2015, 16 students/

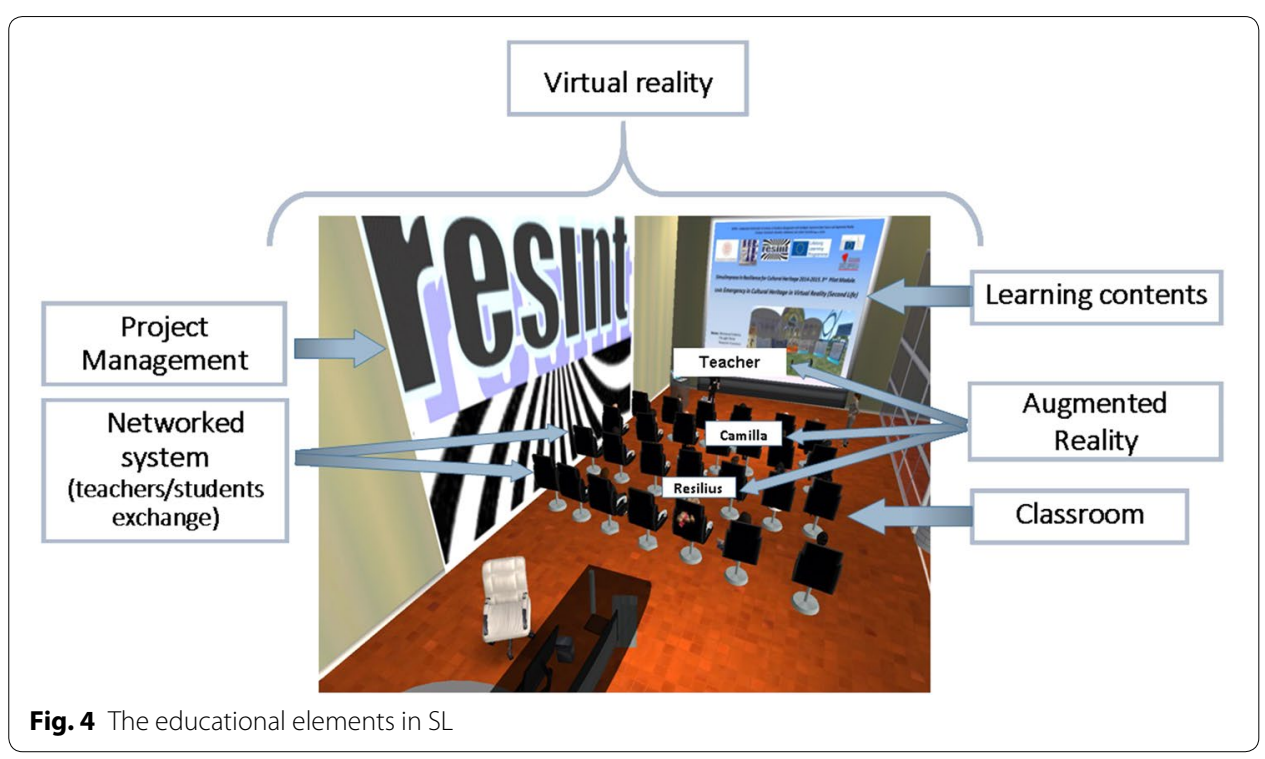


avatars coming from Zuvedra and Celatus PFs participated. In such way, the use of SL allows to beat the physical barriers of distance for the audience of the lecture.

3. All the students were really enthusiastic in learning what is SL and how to enter and use it. Moreover, they had a positive impression to have a seminar/lecture in SL and this strongly emerged in the creation of avatars and in their moving to the lecture room placed in Perting land.

Although these are positive results, one limitation was connected to technical problems of audio that caused some interruptions during the seminars for adjusting and managing the voice and its volume.

Moreover, as in didactic activities for the teacher is very relevant the face to face approach with students to evaluate if they made themselves understood and the level of attention obtained by the class. In SL, this is not possible as may be avatar is seat and seems to listen the lecturer voice whilst in the real environment of classroom the student, behind the avatar, speaks with colleagues or is completely inattentive.

We have also to consider that the graphic is improved in last years making a lecture more corresponding to the real even if this depends from the PC capacity.

While in SL the number of teachers/tutors is limited, the effectiveness of PF methodology requires an adequate number of academic staff (teacher/tutors) as students have to face multidisciplinary activities as for marketing, project management, accounting and $\operatorname{tax}$.

Thus, a different educational profile between PF applied in laboratory and SL emerges as participants diversify their approaches in these methodologies (Tampieri 2012).

First, in PF students acquire knowledge, competencies, capacities and skills on the activities carried out by a real enterprise whilst in SL they realize 3D operations as the creation of offices for avatar-employee and objects to be sold with aim of reproducing a real enterprise in a virtual environment.

The possibility for avatars to buy and sell in SL with a virtual money convertible into the real one made students/avatars very enthusiastic as the orientation for making profit enhances the efforts and engagements to manage this VW (Itzkoff 2007).

In SL avatars can learn from the teachers and tutors, as it happens in laboratory, and also from the virtual environment in which many free access educational centres are located. So in SL the area of learning is wider than in laboratory where the students simulate operations by interacting each other in a limited physical place. Moreover, in the laboratory students acquire specific competencies related to the position inside the enterprise on the basis of the assigned targets at the beginning of each operative lecture.

\section{Conclusions}

Despite the diversity of approaches, the combination of Practice Firm together with Second Life assumes a significant importance in the educational context where it is not always possible to configure in a deterministic way the learning processes. Moreover, the increasing demand to realize a more tight knowledge triangle amongst education, research and innovation creates from one side criticism on the shortage in the teaching of entrepreneurship and at the other motivates the instruments of higher education in the dynamic of knowledge production using students and teachers as a resource. The 
practice management coupled with the virtual world could reduce the distance between the taught theory, particularly in management, and the practice. It means to create a bridge between theory and practice, till now realized by internships or stages before the graduation and by the introduction to the job after the recruitment.

As it concerns the demand of PFs teaching, this could be connected to the search of an answer to the latest criticism on MBA schools and the request of near real-world experiences using simulations and labs (Groth 2014). Other authors argue that this criticism derives from the lack of quality and consistency in the development of general management knowledge (Denning 2013) but really the most of researches on SL was located before 2010 as after the interest diminishes although the increasing diffusion of PFs in Europen-Pen International Network that born in 1997 with 2775 PFs that rise in 2015 to around 7000 involving 42 Countries over the world (http://www.penworldwide.org/).

For this purpose, the prevalence of a practical component in the learning process implemented in PF is integrated, with the use of Second Life, by the virtual dimension that acts as a support to improve the learning by students. Therefore, SL can augment the learning results achieved through PF as a platform to deliver educational contents in a more flexible way.

As it concerns the use of virtual reality, also SL and similar virtual worlds have to face a structural crisis owing to the competition with other social networks (also if SL is not really a social network) and particularly the disaffection of companies in using these virtual worlds owing to the availability of software that can create autonomously virtual and augmented reality experiences in more sophisticated renderings without applying SL or similar platforms.

At the other side, SL ensures to virtual enterprises a not controlled market very similar to the real one also in an attempt to introduce in it illegal activities.

Another limit is concerning SL as a teaching/learning platform because for a real effectiveness it is necessary to use it in connection to other platforms where the teacher can supply students with technical support materials (Esteves et al. 2008).

In UNIBO, the open-source platform MOODLE is used for sharing learning objects amongst users and recently, within the Resint Project, this is combined with BEAT (Bologna E-Learning Authoring Tool) to introduce modules of innovative teaching as simulimpresa pilot courses.

Another field to be addressed is the introduction of courses for SL teachers to disseminate the methodology that cannot be transferred only by theory but with practical training. As it implies a multidisciplinary approach it would be useful for the responsible of SL courses or modules to invite colleagues of other subjects to assist to a PF performance with the aim to individuate the SL appliance to courses, at least as laboratory experiences.

The introduction of PF modules in a compulsory course has to maintain the voluntarism. This can be realized offering the PF module within the course as an optional choice for students between the traditional ones and those of PF.

The main limitation of this analysis is the scarcity of quantitative and qualitative data about SL experience as the study examined the cases from the perspective of the tutor that made a general and basic overview about this didactical tool that is at an early stage of development. 
Further researches would be addressed to widen the cases of study with more PFs and, as it concerns SL, other universities that implement SL for didactical purposes. Researches in progress are dedicated to the process of reproducing an organizational environment as a copy of a real one and as an extension of mirror neurons theory. As this subject represents a novelty, we can mention it just to stimulate further researches in this direction waiting concrete and empirical results.

\section{Abbreviations \\ PF: Practice Firm; SL: Second Life; UNIBO: Bologna University_Forlì School of Economics, Management and Statistics; HEls: Higher Education Institutions; VR: virtual reality; AR: augmented reality; VWs: virtual worlds.}

\section{Authors' information}

LT is Ph.D., Research Fellow at Bologna University-Department of Management. She is project assistant of several national and international research projects. The main research interests are: network analysis; practice management; management and ICTs; project management; performance evaluation.

\section{Competing interests}

The author declares that she has no competing interests.

Received: 10 June 2015 Accepted: 19 November 2015

Published online: 07 December 2015

\section{References}

Billinghurst M, Dunser A (2012) Augmented reality in the classroom. Computer 45:56-63

Coffman T, Klinger MB (2007) Utilizing virtual worlds in education: the implications for practice. Int J Soc Sci 2:29-33

Denning S (2013) What's Wrong With Today's Business Schools? Available via Forbes. http://www.forbes.com/sites/stevedenning/2013/02/26/whats-wrong-with-todays-business-schools/. Accessed 26 Feb 2013

Esteves M, Antunes R, Fonseca B, Morgado L, Martins P (2008) Using Second Life in Programming's communities of practice. In: Briggs RO, Antunes P, de Vreede G, Read AS (eds) Groupware: Design, Implementation, and Use: 14th International Workshop, CRIWG 2008, LNCS 5411. Springer-Verlag, Berlin, Heidelberg, pp 99-106

Fallman D, Backman A, Holmlund K (1999) VR in Education: an introduction to multisensory constructivist learning environments, Universitetspedagogisk konferens, Umea universitet, 18-19 February 1999

Filho WADA, Drakos N, Lundy J (2006) What virtual worlds have to do with Your business life. Gartner Research Publication 22

Foster AL (2008) Using Second Life as platform for education: Professor Avatar. Educ Digest 73:12-17

Groth O (2014) Arrogant MBA students are product of role modelling. In: Financial Times May 4th 2014. http://www. ft.com/cms/s/2/8ee5f616-a3be-11e3-aa85-00144feab7de.html\#axzz3pOfOXbn0. Accessed 4 May 2014

Inman C, Wright VH, Hartman JA (2010) Use of Second Life in K-12 and Higher Education: A Review of Research. Jo Interactive Online Learning 9:44-63

Itzkoff D (2007) A brave new world for TV? Virtually. New York Times, 24 June 2007 from http://www.nytimes. com/2007/06/24/arts/television/24itzk.html?pagewanted=all\&_r=0

Kaplan AM, Haenlein M (2009) The fairyland of Second Life: Virtual social worlds and how to use them. Bus Horiz 52:563-572

Keppell M, Macpherson C (1997) Is the Elephant Really There?-Virtual Reality in Education, Retrieved Jan 03, 2006, from http://www.ddce.cqu.edu.au/ddce/confsem/vr/present.html

Mackenzie K, Buckby S, Irvine H (2009) A framework for evaluating business lead users' virtual reality innovations in Second Life. Electron Commer Res 9:183-202

Mahon J, Bryant B, Brown B, Kim M (2010) Using Second Life to enhance classroom management practice in teacher education. Educ Media Int 47:121-134

Mekni M, Lemieux A (2014) Augmented Reality: Applications, Challenges and Future Trends. In: Zaharim A, Sopian K, Psarris K, Margenstern M (eds) Applied Computational Science-Proceedings of the 13th International Conference on Applied Computer and Applied Computational Science (ACACOS'14) Kuala Lumpur, Malaysia, 23-25 April 2014, pp 205-214

Merchant Z, Goetz ET, Cifuentes L, Keeney-Kennicutt W, Davis TJ (2014) Effectiveness of virtual reality-based instruction on students' learning outcomes in K-12 and higher education: a meta-analysis. Comput Educ 70:29-40

Michels P (2008) Universities use Second Life to teach complex concepts. Govtech.com. Article retrieved 26 March 2009. http://www.govtech.com/gt/252550

Moore P (1995) Learning and teaching in virtual worlds: implications of virtual reality for education. Aust J Educ Technol 11:91-102

Moore A (2004) The Challenge of the Practice Firm: Simulating a Business Environment in the UAE. Paper presented at the Fourth European GIS Education Seminar, Villach, Austria 02-05 September 2004

Reese HW (2011) The learning-by-doing principle. Behav Dev Bull 11:1-19 
Salomon M (2007) Business in Second Life: an introduction. Smart Internet Technology CRC Pty Ltd, Australia, pp 1-26 Tampieri L (2009) Simulazione in Second Life e Business Virtuale nello start up d'impresa del Sistema Moda. CLUEB, Bologna

Tampieri L (2011) Second Life and enterprise simulation in SME's start up of fashion sector: the cases ETNI, KK Personal Robe and NFP. In: D'Atri A, Ferrara M, George JF, Spagnoletti P (eds) Information technology and innovation trends in organizations. Physica-Verlag, Springer, Heidelberg, pp 523-530

Tampieri L (2012) Second Life as Educational Space for the simulation of Enterprises'start up and for managerial culture Development. In: Bates-Brkljac N (ed) Virtual Reality. NOVA Science Publisher, New York, pp 1-50

Tampieri L (2015) Detecting new forms of organizing through ties analysis and mirror neurons' perspective. Paper presented at WOA 2015, University of Padova, 21-22 May 2015

Wang F, Burton JK (2013) Second Life in education: a review of publications from its launch to 2011. Br J Educ Technol 44:357-371

Welch SJ (2007) Get a [Second] Life. Success Meet 56:38-43

Winn W (1993) A conceptual basis for educational applications of virtual reality. HITL Laboratory. http://www.hitl.washington.edu/research/education/winn/winn-paper.html. Accessed Aug 1993

Yuen S, Yaoyuneyong G, Johnson E (2011) Augmented reality: an overview and five directions for ar in education. J Educ Technol Dev Exch 4:119-140

\section{Submit your manuscript to a SpringerOpen ${ }^{\circ}$ journal and benefit from:}

- Convenient online submission

- Rigorous peer review

- Immediate publication on acceptance

- Open access: articles freely available online

- High visibility within the field

- Retaining the copyright to your article

Submit your next manuscript at $\boldsymbol{s p r i n g e r o p e n . c o m ~}$ 